\title{
Thymic Alymphoplasia, Monoclonal Gammopathy, and Pneumocystis Carinii Pneumonia in an Infant
}

\author{
D. M. O. BECROFT and R. DOUGLAS \\ From the Princess Mary Hospital for Children, and the Auckland Blood Transfusion Service, \\ Auckland, New Zealand
}

Immunological deficiencies have been shown in many children bearing thymic malformations. In some children both cell-mediated and humoral immune reactions have been depressed, the former indicated by abnormalities of delayed hypersensitivity and of homograft rejection, and the latter by deficient antibody responses and hypo- $\gamma$-globulinaemia. Such findings are in accord with the experimental evidence that the thymus acts as a 'protagonist in the development of immunological capacity' (Holborow, 1967). Unfortunately, the inconstancy of these deficiencies in other cases has prevented a more precise definition of the role of the thymus in human immunogenesis. Not all children with congenital thymic defects have been hypo- $\gamma$-globulinaemic, though the patterns of immunoglobulin synthesis in these exceptions have varied widely and have often been abnormal.

The infant with thymic dysplasia who is the subject of this report presented a further variation in having an immunoglobulin with the restricted electrophoretic and antigenic properties characteristic of the $\mathrm{M}$-type proteins found in multiple myeloma and related neoplastic diseases.

\section{Case Report}

This male infant, birthweight $2.9 \mathrm{~kg}$., was delivered normally after an uneventful pregnancy. He progressed satisfactorily for 4 weeks, but then began vomiting; pyloric stenosis was suspected, and he was admitted to hospital. At 4 weeks old he weighed $3.3 \mathrm{~kg}$. No abnormalities were found clinically. A barium meal showed gastro-oesophageal reflux, and with feeding in the upright position and sedation he vomited less and gained a little weight. During this admission his blood $\mathrm{Hb}$ and urea, serum electrolytes, calcium and phosphorus, urine analysis, and chest $x$-ray were normal. His white blood counts are listed in Table I.

Received January 29, 1968.
He was readmitted aged 12 weeks because he had failed to gain weight. He then weighed $3.8 \mathrm{~kg}$. He was small and thin, but there were no other clinical abnormalities. $X$-rays of his chest showed a minor focal accentuation of lung markings. His serum electrolytes, calcium, phosphorus, and glucose, and his blood urea were again normal. Hb 10.9 g. $/ 100 \mathrm{ml}$. There was a nasal discharge from which Staphylococcus pyogenes was cultured. Urine analysis was normal. He remained in hospital vomiting intermittently and having some diarrhoea, but these symptoms were never severe enough to cause dehydration. After 2 weeks a macular rash appeared on his trunk and persisted. The skin of his buttocks and ano-genital area became excoriated. He had oral moniliasis which was resistant to therapy, and it was suspected that the skin was similarly infected. He gained weight very slowly.

After 8 weeks in hospital he became dyspnoeic and cyanosed. There was clinical and radiological evidence of consolidation advancing through the lung fields. His condition deteriorated rapidly and he died at 20 weeks. Hb terminally was $12 \cdot 2 \mathrm{~g} . / 100 \mathrm{ml}$. and the red cell morphology was normal.

Necropsy. The body was poorly nourished (weight $4.9 \mathrm{~kg}$., crown-heel length $61 \mathrm{~cm}$.). There was a diffuse macular rash merging into confluent, partly crusted erythema over the neck, groins, buttocks, and perineum. The lungs were uniformly firm and heavy. In all

TABLE I

White Blood Counts

\begin{tabular}{c|c|c}
\hline Age (wk.) & $\begin{array}{c}\text { Total } \\
\text { WBC/cu.mm. }\end{array}$ & $\begin{array}{c}\text { Absolute } \\
\text { Lymphocyte } \\
\text { Count/cu.mm. }\end{array}$ \\
\hline 4 & 7,900 & 790 \\
6 & 5,000 & 1,500 \\
12 & 10,400 & 3,800 \\
16 & 9,600 & 3,900 \\
20 & 15,800 & 6,800 \\
21 & 23,100 & 4,200 \\
21 & 19,300 & 3,900 \\
\hline
\end{tabular}




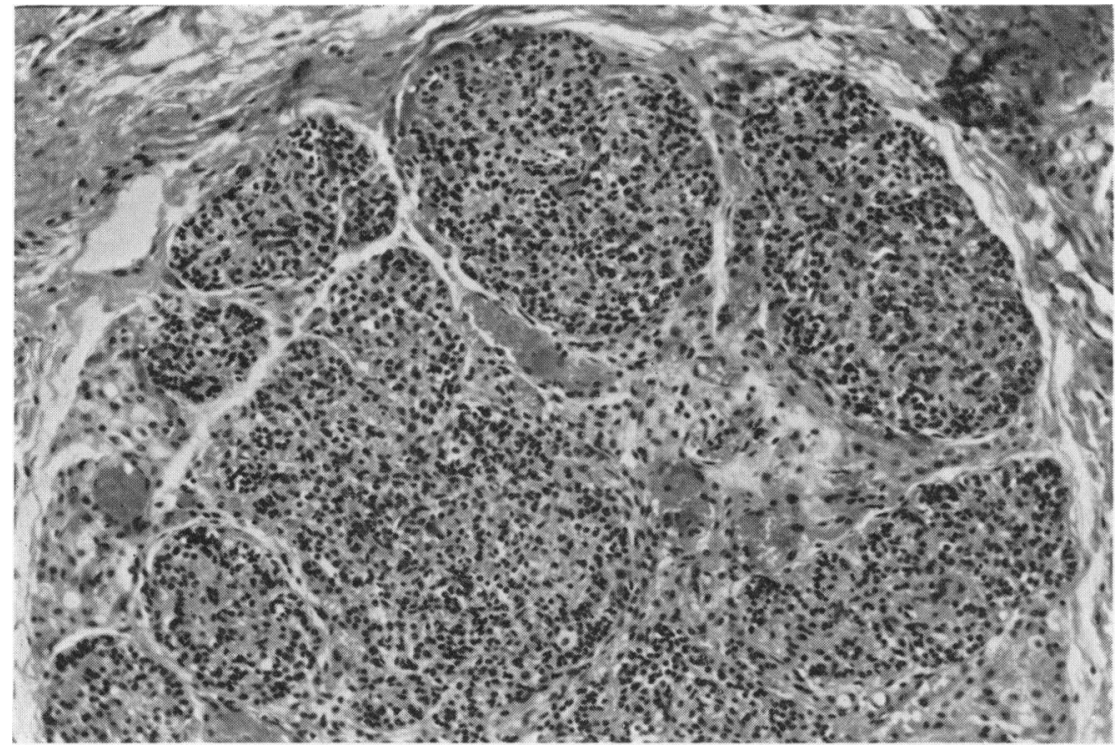

Fig. 1.-Thymus: the dysplastic lobules contain few lymphocytes and no Hassall's corpuscles. $(H$. and $E . \quad \times 145$.

histological sections the majority of alveolar ducts and alveoli contained a foamy exudate characteristic of Pneumocystis carinii infection, and typical organisms were demonstrated in smears and sections (Becroft and Costello, 1965). There was a patchy interstitial and peribronchiolar infiltration by lymphocytes and numerous pyroninophilic plasmacytes and proplasmacytes.

The thymus was a small, firm, white nodule in the superior mediastinum weighing less than $1 \mathrm{~g}$. In sections the thymic lobules were well defined, but extremely small, consisting largely of epithelial thymocytes (Fig. 1). Hassall's corpuscles were absent and there were only a few small lymphocytes.

Many retro-peritoneal and mesenteric lymph nodes were enlarged to as much as $2 \mathrm{~cm}$. in diameter. All nodes examined histologically lacked normal differentiation into a cortex and medulla, and consisted of a loose stromal network containing numerous reticular cells with well-defined eosinophilic cytoplasm (Fig. 2). Lymphocytes were sparse, and though some were aggregated about arterioles, there were no true primary or secondary follicles. Plasmacytes and pro-plasmacytes were abundant in all nodes (Fig. 3).

The spleen weighed $20 \mathrm{~g}$. Penicilliary arteries were surrounded by fibrillary zone containing loosely arranged reticular cells, plasmacytes, and a homogeneous eosinophilic deposit which did not retain stains for amyloid (Fig. 4). These pale-staining areas had a peripheral cuff of lymphocytes varying from a few cells to welldeveloped lymphoid follicles without germinal centres. There were many plasmacytes in the red pulp. In the liver some portal tracts contained small aggregations of lymphocytes, reticular cells, and many plasmacytes. On macroscopic inspection no tonsillar tissue was apparent and the appendix was normal, but no sections were available from these organs. No submucosal lymphoid tissue was detected in serial sections of the small and large intestines. The lamina propria of the intestines was poorly cellular, but did contain scattered plasmacytes and lymphocytes. The bone-marrow had normal cellularity. Some lymphocytes and plasmacytes were identified, but in sections were difficult to distinguish from other marrow elements. No abnormalities were detected in other organs.

\section{Serum Immunoglobulins}

Hyper- $\gamma$-globulinaemia was first demonstrated by paper electrophoresis of serum when the patient was 12 weeks old, but the presence of a discretely migrating component was overlooked at the time (Fig. 5a). Total serum proteins were then $6.6 \mathrm{~g} . / 100 \mathrm{ml}$., and the serum $\gamma$-globulin level (by elution) was $1.3 \mathrm{~g} . / 100 \mathrm{ml}$. All other investigations were performed on serum obtained post mortem; the validity of such specimens for protein studies has been confirmed by Martinez-Tello and Braun (1965). Total serum proteins were $6.6 \mathrm{~g} . / 100$ $\mathrm{ml}$. By photometric scanning after electrophoresis on cellulose acetate the serum albumin was estimated as $2.9 \mathrm{~g} . / 100 \mathrm{ml}$, and serum $\gamma$-globulin as $2.0 \mathrm{~g} . / 100 \mathrm{ml}$. Immunoassays of immunoglobulin fractions (performed in the laboratory of Dr. David Gitlin by methods similar to those described by Fireman, Johnson, and Gitlin, 1966): IgG $1800 \mathrm{mg}$./100 ml.; IgA $180 \mathrm{mg}$./100 $\mathrm{ml}$; and IgM approximately twice the normal adult level. An independent immunoassay (by Dr. John Scott using the method of Soothill, 1962) gave an even 


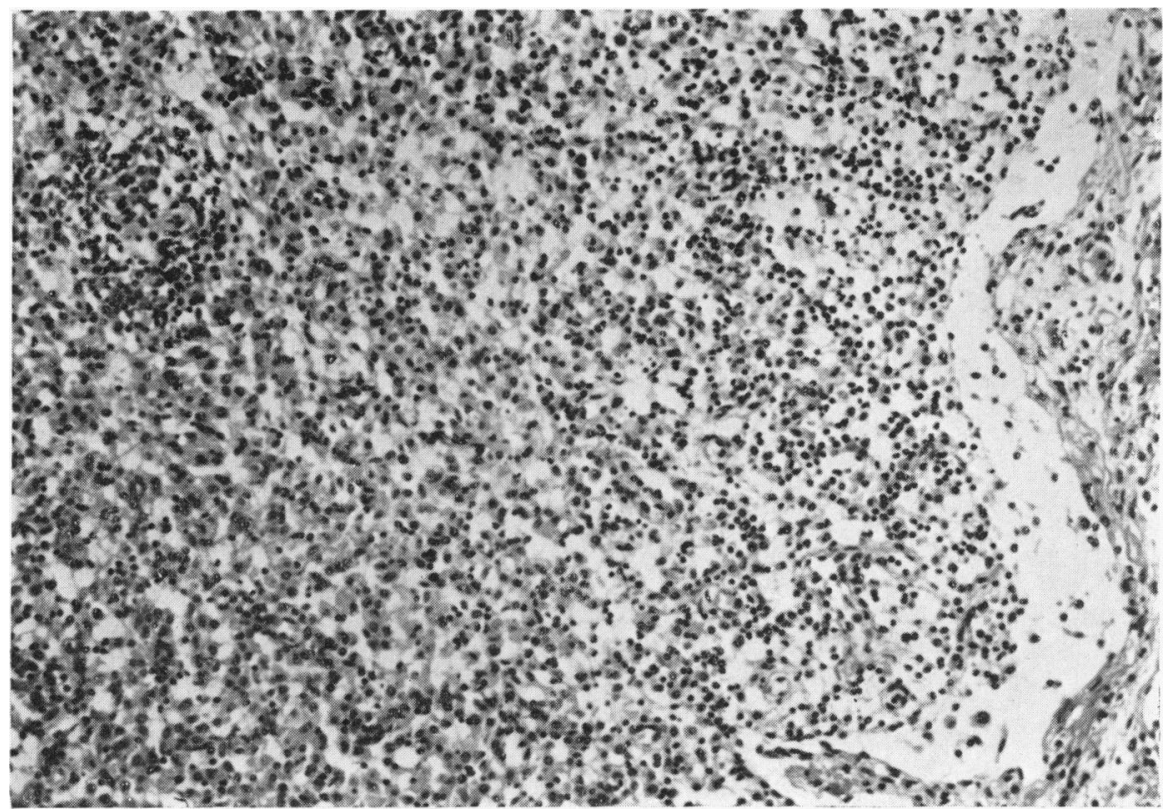

Fig. 2.-Lymph node: subcapsular region showing severe depletion of lymphocytes and hyperplasia of reticular cells. (H. and $E . \quad \times 145$.

higher IgG level of $2400 \mathrm{mg} . / 100 \mathrm{ml}$. $( \pm 400 \mathrm{mg}$./100 ml.).

Discrete electrophoretic migration of a large slowmoving fraction of the $\gamma$-globulin was noted on cellulose acetate and was particularly striking on starch gel. On the latter, one major band characteristic of an M-component and at least one minor band were apparent (Fig. $5 b)$. Immunoelectrophoresis revealed IgA and $\operatorname{IgM}$ to

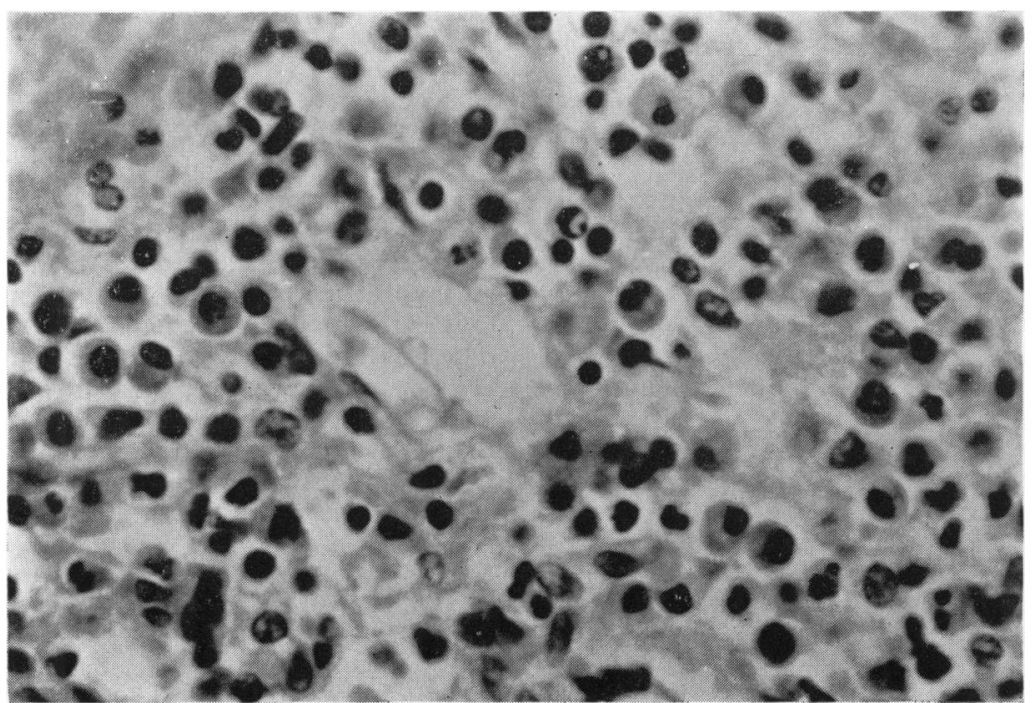

FIG. 3.-Lymph node: higher magnification than Fig. 2, showing numerous plasmacytes and proplasmacytes. (H. and $E . \quad \times 640$. 


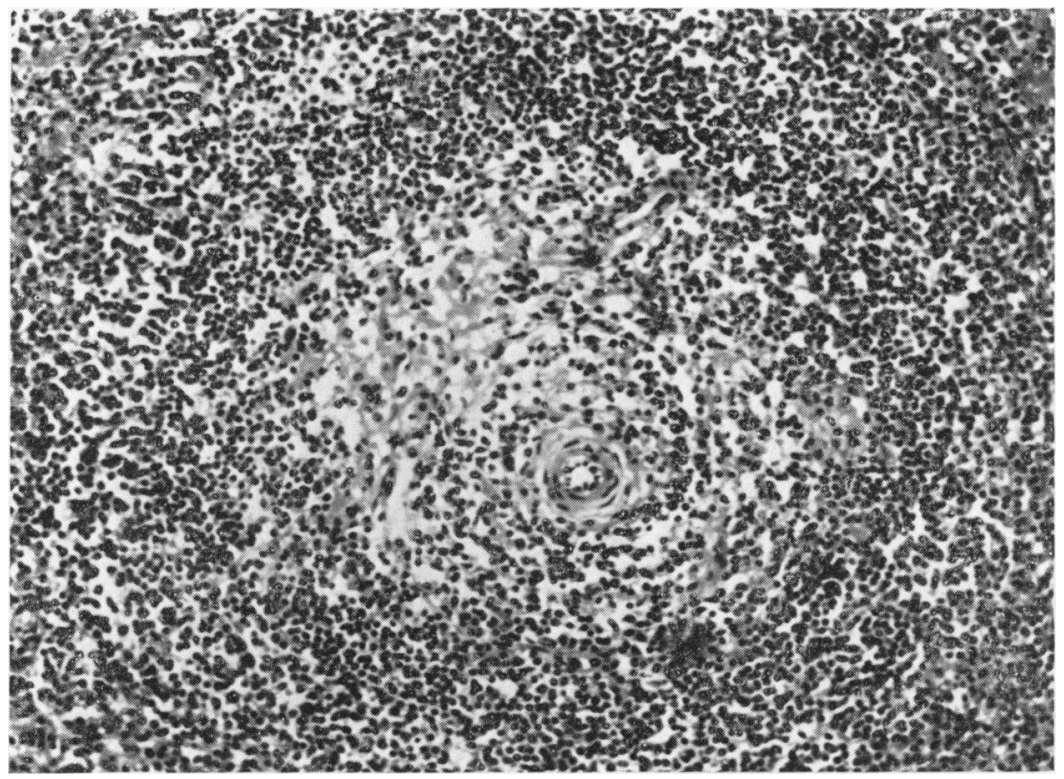

Fig. 4.- Spleen: lymphoid follicle having a central pale area containing plasma cells and a proteinaceous deposit, but no germinal centre. (H. and $E . \quad \times 145$.)

be present in amounts consistent with the above quantitative estimations. The precipitin arcs of these fractions had normal configuration, whereas the IgG arc was distorted, with bowing towards the antibody reservoir in the slow-moving region consistent with the presence of the discretely migrating abnormal component (Fig. 5c). The presence of both $\mathrm{K}$ and $\mathrm{L}$ antigens in the unfractionated serum was confirmed using an Ouchterlony plate technique and antisera to $\kappa$ and $\lambda$ light polypeptide chains (Hyland Laboratories). Relative to normal sera, $\mathrm{K}$ antigens were present in approximately normal amounts and $\mathrm{L}$ antigens in considerable excess. Dr. Morten Harboe and his associates confirmed these quantitative differences by immunoelectrophoresis using anti-(Fab' $)_{2}$ antisera absorbed with type $K$ and type $L$ Bence Jones proteins to produce anti-type $\mathrm{L}$ and $\mathrm{K}$ specificities, respectively (methods similar to those described by Harboe, Deverill, and Godal, 1965). The precipitin arc in the IgG region produced by type $\mathrm{L}$ antisera was again heavy and showed localized deviation towards the antibody reservoir, whereas the relatively light arc produced by type $K$ antisera had normal configuration, i.e. only type $\mathrm{L}$ antigens were detectable in the discretely migrating immunoglobulin fraction. The $\gamma$-globulins of the only sib, a healthy older brother, and of his parents had normal electrophoretic properties, and normal IgG levels were shown by immunological assays.

Genetic determinants (Moullec et al., 1956). Patient: $-\mathrm{Gm}$ a,$+ \mathrm{b}+, \mathrm{c}-, \mathrm{x}-$. Inv $\mathrm{a}-$.

Both parents: $-\mathrm{Gm} \mathrm{a}+, \mathrm{b}+, \mathrm{c}-, \mathrm{x}+$. Inv $\mathrm{a}-$.

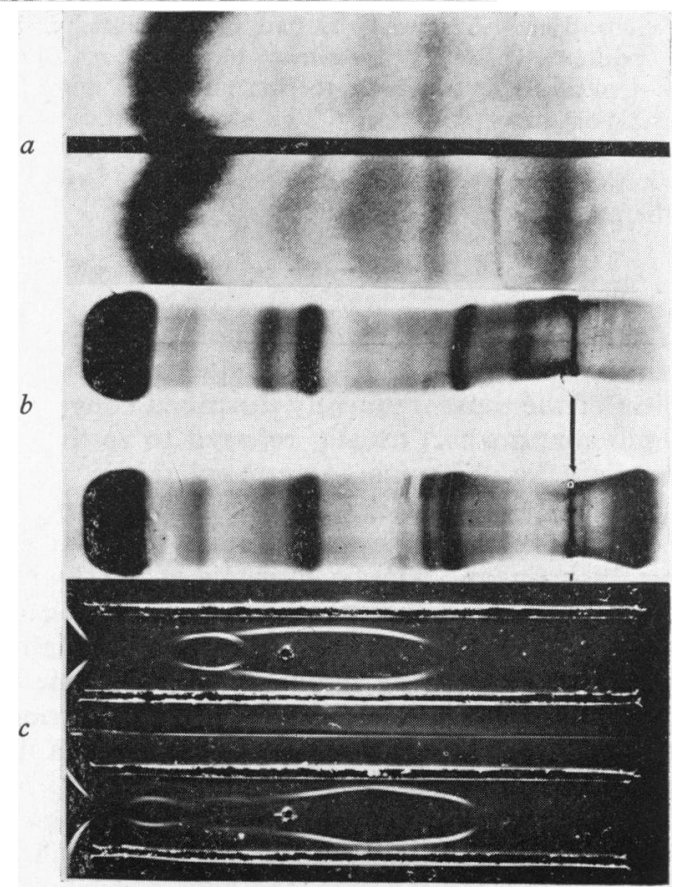

FIG. 5.-Electrophoresis of serum proteins, in each pair contrasting the patient's serum (below), containing a discretely migrating $\gamma$-globulin component, with pooled normal human sera (above). (a) Paper electrophoresis, patient aged 12 weeks; (b) starch gel (tris-borate buffer $\mathrm{pH}$ 8.6), post-mortem serum; (c) immunoelectrophoresis of post-mortem serum; antiserum with IgG specificity; IgG arc is distorted. 
TABLE II

Immunoglobulins in Histologically-proven Thymic Alymphoplasia

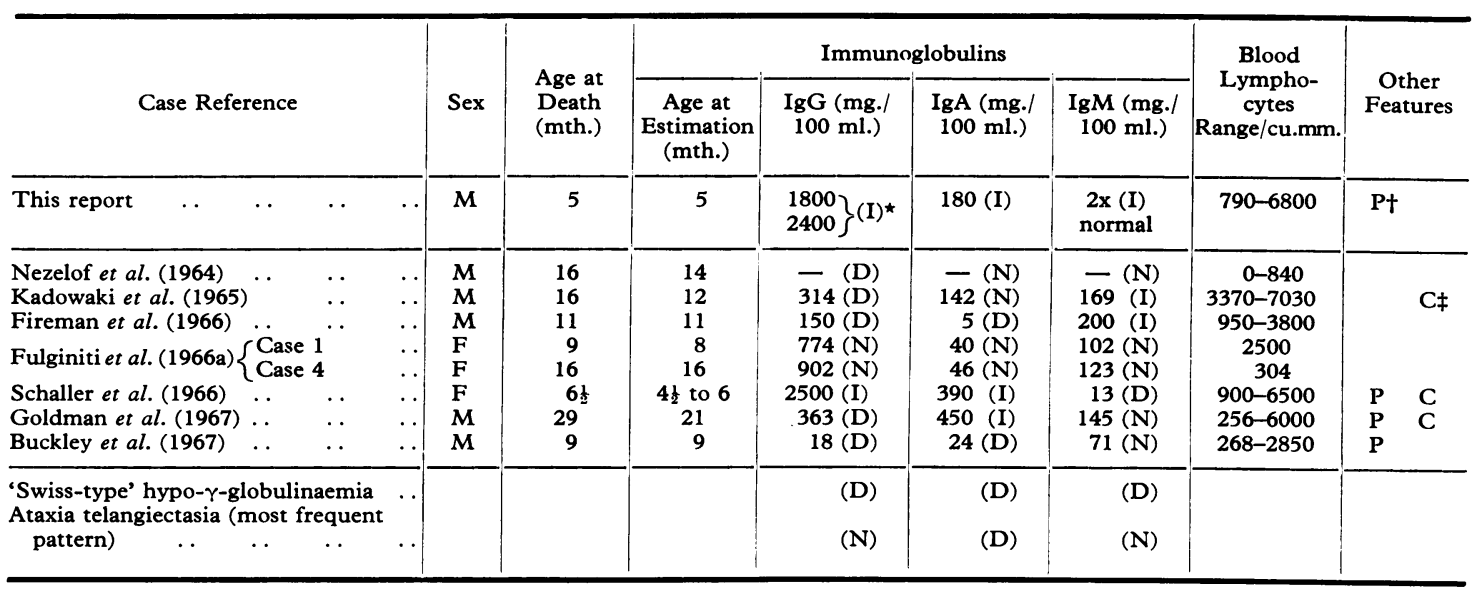

$\star N$, normal; D, decreased; I, increased (authors' interpretation).

$\dagger \mathbf{P}$, Pneumocystis pneumonia.

$\ddagger$ C, Positive Coombs' test.

Antibodies. A myxovirus had been isolated from the patient's pharynx 8 weeks before death. No complement-fixing antibody to this virus was detected in the post-mortem serum. The blood groups of the patient and of the parents were all Group O D positive. No anti-A or anti-B isohaemagglutinins were detected in the patient's serum.

\section{Discussion}

The severe lymphoid depletion and dysplasia of epithelial elements in this infant's thymus are typical of the most frequently described congenital thymic abnormality, usually referred to as thymic alymphoplasia. Thymic alymphoplasia in early reports was associated with the severe impairment of cell-mediated and humoral immune reactions, short life-span, and lymphocytopenia of the 'Swisstype' of hypo- $\gamma$-globulinaemia (Gitlin and Craig, 1963). However, our patient is at least the eighth now reported as having significant levels of one or more of the major serum immunoglobulin fractions IgG, IgM, or IgA, in the presence of histologically proven thymic alymphoplasia (Table II). Patients with the genetically distinct entity ataxia telangiectasia have been excluded from this list, as well as others with similar illnesses who have recovered or whose thymic deformities were less severe. The absolute levels of the immunoglobulins in these patients cannot be compared, because different methods were used for the quantitation, but on the basis of the authors' interpretation of these as normal, increased, or decreased, 7 patterns are apparent. All are different from that in our patient, in whom all 3 components were increased, IgG in particular 4- to 5-fold over the mean level of normal infants of his age (Fulginiti et al., 1966b; Stiehm and Fudenberg, 1966).

The more exceptional finding was that the greater part of his IgG had the electrophoretic properties of an $M$-type paraprotein. These proteins are rare in infancy, and it is of interest that an infant with paraproteinaemia, described by Stoop, Ballieux, and Weyers (1962), had severe lymphoid depletion in the thymus, spleen, and lymph nodes, and clinical features similar to the present patient. Stoop et al. could find only one previous description of an infant with paraproteinaemia. There have been few reports subsequently, and fewer where conformity with more recently defined M-type characteristics can be claimed from the demonstration of a great preponderance of one type of light polypeptide chain (Fahey and Solomon, 1963). The presence of large amounts of an M-type or 'monoclonal' protein in an adult would, in the first instance, require exclusion of myelomatosis or other malignancy. Myelomatosis does not appear to have been described in an infant, and, though plasma cells were abundant in our patient's tissues, they did not have neoplastic characteristics. On the other hand, children with thymic alymphoplasia are predisposed to lymphoid and lymphohistiocytic neoplasms (Peterson, Cooper, and Good, 1965; Goldman et al., 1967), but the hyperplasia of reticular cells in our patient was clearly benign histologically and of a type also described frequently in thymic alymphoplasia. 
Other changes in his lymphoid tissues, particularly depletion of lymphocytes and defective follicular development, were similar to those described in 'Swiss-type' hypo- $\gamma$-globulinaemia and, despite hyper- $\gamma$-globulinaemia, his clinical course was also in most respects typical of the 'Swiss-type' of immunological disorder (Rosen and Janeway, 1966). The presence of pneumocystis pneumonia is indicative of a severe immunological deficiency. Lymphopenia, though not now considered a consistent feature of the 'Swiss-type' disease, was present early in his illness. When the cases of thymic alymphoplasia in Table II are compared with the larger series reviewed by Haworth, Hoogstraten, and Taylor (1967), it is apparent that the presence or absence of immunoglobulins has had little effect on the course of their disease. The suggestion by Rosen and Janeway (1966) that all cases are manifestations of a single genetic entity affecting thymic development lacks confirmation. Sibs of 7 children with immunoglobulins listed in Table II had a history of a similar disease, but none were known to be hypo- $\gamma$-globulinaemic.

The failure of both endogenous and therapeutically administered immunoglobulins to modify the disease associated with thymic alymphoplasia could be due to dominance of associated defects in cellular immunity. Cell-mediated immune reactions were not investigated in our patient, but defects have been demonstrated in other cases with immunoglobulins (Schaller et al., 1966; Buckley, Bradford, and Butcher, 1967). As an added factor, some of these cases with immunoglobulins appear to have a limited capacity for an antibody response. Our patient's serum did not contain antibodies to a recent virus infection. This might reflect the usual absence of demonstrable biological activity in M-type proteins, but even in the presence of adequate levels of electrophoretically normal IgG some children with thymic alymphoplasia have not developed antibodies against bacterial and viral antigens (Schaller et al., 1966; Goldman et al., 1967). Though these findings are consistent with the suggestion by Peterson et al. (1965) that normal development of the thymus is necessary for the recognition of antigenicity, the debilitated state of some patients may provide an alternative explanation. Furthermore, antibodies were demonstrated in the case reported by Nezelof et al. (1964).

Therefore, one possible explanation for immunoglobulin synthesis in some cases of thymic alymphoplasia and of the M-type proteinaemia in our patient is an exposure to special antigenic stimuli not encountered by others. Both pneumocystis infection and auto-immune processes have to be con- sidered in this role because each was present in several children listed in Table II. However, pneumocystis infection has been described in many persistently hypo- $\gamma$-globulinaemic cases; and the neonatal form of this infection, with an even more intense pulmonary plasmacytosis than that in our patient, occurs without an immunoglobulin response, or one limited to IgM (Ivády et al., 1967). Coombs positivity was demonstrated in 3 patients in Table II, including the only child with hyper- $\gamma$-globulinaemia comparable to that in our patient, and a similar association between auto-immunity and hyper- $\gamma$ globulinaemia has been described in the experimentally thymectomized animal (Sutherland et al., 1965). Our patient, however, had no evidence of autoimmune disease.

Alternatively, previous authors have noted that the presence of immunoglobulins in some children with thymic defects is consistent with experimental evidence that the development of the immunoglobulin system is independent of the thymus ( $\mathrm{Di}$ George et al., 1967). Neonatal thymectomy in several species impairs cell-mediated immune reactions, whereas hypo- $\gamma$-globulinaemia has been produced only by ablation of other primary lymphoid organs (Peterson et al., 1965; Miller, 1966). No comparable anatomical difference has been detected in cases of thymic alymphoplasia, which would correlate with their variable immunoglobulin synthesis.

As a further alternative, Kadowaki et al. (1965) have presented cytogenetic evidence to suggest that the immunoglobulins in their case of thymic alymphoplasia were the product of a graft of maternal immuno-competent cells. It was hoped that a similar origin of our patient's immunoglobulins would be excluded by the demonstration of paternal genetic determinants, but these investigations were frustrated by the parents having identical $\mathrm{Gm}$ and Inv types.

Precedents for the occurrence of M-type proteinaemia in association with a congenital immunological deficiency state have been established in animals, in which the immunological defects were induced experimentally (Humphrey, Parrott, and East, 1964; Pierce, Chubb, and Long, 1966), and in man, following the grafting of lymphoid cells into an infant with 'Swiss-type' hypo- $\gamma$-globulinaemia (Harboe et al., 1966). The explanation offered in each instance was that cloning of immunoglobulinproducing cell lines had limited subsequent synthesis to an abnormally homogeneous protein. The M-type proteinaemia in our patient may have been the result of similar cloning occurring in the course of abnormal immunogenesis. A prerequisite for 
such a theory is that individual immunoglobulinproducing cells are limited in their synthesis to a single type of light chain and single heavy chain, for which there is limited evidence in man (Bernier and Cebra, 1964).

\section{Summary}

Paradoxical hyper- $\gamma$-globulinaemia and tissue plasmacytosis were demonstrated in a 5-month-old male infant with thymic alymphoplasia. His death from Pneumocystis carinii pneumonia indicated an immunological deficiency state, while other features of his illness and the pathological findings in lymphoid tissues closely resembled those seen in the 'Swiss-type' of hypo- $\gamma$-globulinaemia. The serum immunoglobulin fractions $\operatorname{IgG}, \operatorname{IgA}$, and $\operatorname{IgM}$ were all increased, IgG 4- to 5-fold over the mean of normal infants in his age. The greater part of the IgG was electrophoretically homogeneous and was identified as a M-type or 'monoclonal' immunoglobulin with type $\mathrm{L}$ light chains. This rare occurrence of an M-type protein in an infant may have been the result of cloning of immunoglobulinproducing cells during the induction of his immunological deficiency state.

Dr. R. H. Caughey kindly gave permission to report this case. We wish to thank Dr. Morten Harboe, Professor David Gitlin, and Dr. John Scott for their comments and permission to include the results of their investigations, Professor Robert A. Good for valuable advice, and Dr. J. F. Burton for virological studies.

\section{REFERENCES}

Becroft, D. M. O., and Costello, J. M. (1965). Pneumocystis carinii pneumonia in siblings: diagnosis by lung aspiration. N.Z. med. F., 64, 273.

Bernier, G. M., and Cebra, J. J. (1964). Polypeptide chains of human gamma-globulin: cellular localization by fluorescent antibody. Science, 144, 1590.

Buckley, R. H., Bradford, W. D., and Butcher, S. R. (1967). Sslective immunoglobulin deficiency associated with thymic alymphoplasia. Pediatrics, 39, 506.

Di George, A. M., Lischner, H. W., Dacou, C., and Arey, J. B. (1967). Absence of the thymus. Lancet, 1, 1387.

Fahey, J. L., and Solomon, A. (1963). Two types of $\gamma$-myeloma proteins, $\beta_{2}$-A-myeloma proteins, $\gamma_{1}$-macroglobulins and Bence Jones proteins identified by two groups of common antigenic determinants. f. clin. Invest., 42, 811 .

Fireman, P., Johnson, H. A., and Gitlin, D. (1966). Presence of

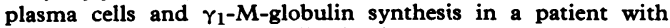
thymic alymphoplasia. Pediatrics, 37, 485.

Fulginiti, V. A., Hathaway, W. E., Pearlman, D. S., Blackburn, W. R., Reiquam, C. W., Githens, J. H., Claman, N. N., and Kempe, C. H. (1966a). Dissociation of delayed-hypersensitivity and antibody-synthesizing capacities in man. Report of two sibships with thymic dysplasia, lymphoid tissue depletion, and normal immunoglobulins. Lancet, 2, 5.

—, Sieber, O. F., Jr., Claman, H. N., and Merrill, D. (1966b). Serum immunoglobulin measurement during the first year of life and in immunoglobulin deficient states. F. Pediat., 68, 723.

Gitlin, D., and Craig, J. M. (1963). The thymus and other lymphoid tissues in congenital agammaglobulinemia. I. Thymic alymphoplasia and lymphocytic hypoplasia and their relation to infection. Pediatrics, 32, 517.

Goldman, A. S., Haggard, M. E., McFadden, J., Ritzmann, S. E. Houston, E. W., Bratcher, R. L., Weiss, K. G., Box, E. M., and Szekrenyes, J. W. (1967). Thymic alymphoplasia, lymphoma, and dys- $\gamma$-globulinemia. Hyper- $\gamma-\mathrm{A}-$, normo- $\gamma \mathrm{M}-$, hypo- $\gamma \mathrm{G}-$ $\mathrm{a}-\gamma \mathrm{D}-$, and $\gamma \mathrm{E}-\mathrm{globulinemia,} \mathrm{plasmacytosis,} \mathrm{normal} \mathrm{delayed}$ hypersensitivity, severe allergic reactions, and Coombs' positive anemia. ibid., $39,348$.

Harboe, M., Deverill, J., and Godal, H. C. (1965). Antigenic heterogeneity of Waldenström type $\gamma \mathrm{M}$-globulins. Scand. $\mathcal{f}$. Haemat., 2, 137.

- , Pande, H., Brandtzaeg, P., Tveter, K. L., and Hjort, P. F. (1966). Synthesis of donor-type $\gamma$ G-globulin following thymus transplantation in hypo- $\gamma$-globulinaemia with severe lymphocytopenia. ibid., 3, 351 .

Haworth, J. C., Hoogstraten, J., and Taylor, H. (1967). Thymic alymphoplasia. Arch. Dis. Childh., 42, 40.

Holborow, E. J. (1967). An ABC of modern immunology. VII. The genesis of immunological competence. Lancet, 1, 1148.

Humphrey, J. H., Parrott, D. M. V., and East, J. (1964). Studies on globulin and antibody production in mice thymectomized at birth. Immunology, 7, 419.

Ivády, Gy., Páldy, L., Koltay, M., Toth, G., and Kovács, Z. (1967). Pneumocystis carinii pneumonia. Lancet, 1, 616.

Kadowaki, J.-I., Thompson, R. I., Zuelzer, W. W., Woolley, P. V., Jr., Brough, A. J., and Gruber, D. (1965). XX/XY lymphoid chimaerism in congenital immunological deficiency syndrome with thymic alymphoplasia. ibid., 2, 1152 .

Martinez-Tello, F., and Braun, D. (1965). Uber Anwendungsmöglichkeiten der post-mortalen Serumanalyse in der Obduktionsdiagnostik besonders bei Paraproteinosen. Virchows Arch. path. Anat., 339, 349.

Miller, J. F. A. P. (1966). Immunity in the foetus and the new-born. Brit. med. Bull., 22, 21.

Moullec, J., Kherumian, R., Sutton, E., and Espagnon, P. (1956). Contribution à l'étude du facteur de groupe $\mathbf{G m}^{\mathrm{a}}$ du plasma humain. Rev. Hémat., 11, 512.

Nezelof, C., Jammet, M. L., Lortholary, P., Labrune, B., and Lamy, M. (1964). L'hypoplasie héréditaire du thymus. Arch. frans. Pédiat., 21, 897.

Peterson, R. D. A., Cooper, M. D., and Good, R. A. (1965). The pathogenesis of immunologic deficiency diseases. Amer. $\mathcal{F}$. Med., 38, 579.

Pierce, A. E., Chubb, R. C., and Long, P. L. (1966). The significance of the bursa of Fabricius in relation to the synthesis of $7 \mathrm{~S}$ and $19 \mathrm{~S}$ immune globulins and specific antibody activity in the fowl. Immunology, 10, 321 .

Rosen, F. S., and Janeway, C. A. (1966). The gammaglobulins. III. The antibody deficiency syndromes (concluded). New Engl. F. Med., 275, 769.

Schaller, J., Davis, S. D., Ching, Y.-C., Lagunoff, D., Williams, C. P. S., and Wedgwood, R. J. (1966). Hypergammaglobulinaemia, antibody deficiency, autoimmune haemolytic anaemia, and nephritis in an infant with a familial lymphopenic defect. Lancet, $2,825$.

Soothill, J. F. (1962). Estimation of eight serum proteins by a gel diffusion precipitin technique. f. Lab. clin. Med., 59, 859.

Stiehm, E. R., and Fudenberg, H. H. (1966). Clinical and immunologic features of dysgammaglobulinemia Type I. Amer. $f$. Med., 40, 805.

Stoop, J. W., Ballieux, R. E., and Weyers, H. A. (1962). Paraproteinemia with secondary immune globulin deficiency in an infant. Pediatrics, 29, 97.

Sutherland, D. E. R., Archer, O. K., Peterson, R. D. A., Eckert, E., and Good, R. A. (1965). Development of 'autoimmune processes' in rabbits after neonatal removal of central lymphoid tissue. Lancet, 1, 130. 